\title{
ILDEFONS HERWEGEN I ROMANO GUARDINI - PREKURSORZY RUCHU LITURGICZNEGO W NIEMCZECH
}

Rewolucja francuska, ze swym niszczycielskim antychrześcijańskim wandalizmem i krwawymi prześladowaniami, mordując francuskie duchowieństwo i stosując po raz pierwszy w skali masowej ludobójstwo wobec mieszczan i chłopów broniących wiary, wydawało się, że doprowadziła do wyrwania dziedzictwa chrześcijańskiego ze swego podłoża ewangelicznego. Jednakże „największe okrucieństwa ateistycznych katów nie zdołały wykorzenić wiary, która przetrwała dzięki niezłomnej postawie milionów Francuzów, w większości prostych ludzi, takich jak zbuntowani wieśniacy w Wandei. A także dzięki niezłomności tysięcy księży z ówczesnego francuskiego „Kościoła katakumb", którzy z narażeniem życia docierali do wiernych, odprawiając tajne Msze Święte w najróżniejszych miejscach, częstokroć w starych spichrzach i stajniach. Ze strasznych prześladowań doby Rewolucji Francuskiej Kościół wyszedł jednak moralnie wzmocniony i oczyszczony. (...) Okrutny czas prześladowań pokazał..., że Kościół miał jakże wielu prawdziwie oddanych duszpasterzy i jakże wielu prawdziwie szczerych obrońców wśród Narodu." Po rewolucji, po latach systematycznego niszczenia życia religijnego, po ciagłych przeobrażeniach politycznych i społecznych, trzeba było zatem odbudować katolicyzm, tak aby odnalazł swą pełną żywotność. Do takiej odbudowy zaczęło przystępować wielu ówczesnych, oddanych sprawie duchownych i ludzi świeckich, którzy usiłowali dokonywać odnowy chrześcijaństwa zwłaszcza w dziedzinie filozofii, życia społecznego i politycznego. Okazało się jednak wkrótce, że najlepszą drogę do odnowy życia religijnego i niejako rechrystianizacji Francji, wybrał Prosper Guéranger OSB, który postanowił dążyć do zamierzonego celu poprzez wskrzeszenie opactwa benedyktyńskiego w Solesmes, tak aby stało się centrum modlitwy i studium, w służbie Kościoła oraz przez odrodzenie życia liturgicznego ${ }^{2}$. P. Guéranger uważał, że oficjum i życie liturgiczne jest głównym środkiem uświęcenia i rozwoju życia duchowego nie tylko zakonników, ale źródłem odnowy chrześcijańskiej życia Ko-

${ }^{1}$ J. R. N o w a k, Kościół a rewolucja francuska, Szczecinek 1999, s. 104 n.

${ }^{2}$ S. K o p e r e k, Dom Prosper Guéranger - opat z Solesmes inspirator wspótczesnej odnowy liturgicznej, „Ruch Biblijny i Liturgiczny” (dalej: RBL) 29:1976, s. 214. 
ścioła i całego narodu. Odnowę tę rozpoczął on w Solesmes, ale jego wpływ ogarnął wnet klasztory Belgii, Niemiec i Austrii, i został podjęty przez znanych teologów i liturgistów tej miary, co Lambert Beauduin, Romano Guardini, Odo Casel, Pius Parsch i inni ${ }^{3}$. O ile odnowa liturgiczna po Soborze Watykańskim II dokonuje się niejako „odgórnie” i w całym Kościele, o tyle z końcem XIX i w pierwszej połowie XX wieku, była dziełem „oddolnym”, poszczególnych inspiratorów i promotorów (tych, którzy byli liturgiae cultores et amatores) oraz takich ośrodków, jak Solesmes, Maria Laach, Mont-César (Louvain), Beuron czy Klosterneuburg.

Ruch liturgiczny, który zaczął się rozwijać we Francji i Belgii, napotkał bardzo sprzyjająca atmosfere w Niemczech, której znakiem było przede wszystkim bogactwo życia monastyczno-liturgicznego Benedyktynów z Beuron oraz postawa pełnego „otwarcia” ze strony ludzi świeckich, zwłaszcza ze środowisk uniwersyteckich ${ }^{4}$. Zainteresowanie liturgią u świeckich, w latach bezpośrednio poprzedzających pierwszą wojnę światowa, bardzo wymownie scharakteryzował w 1912 roku Hermann Platz, późniejszy znany uczony z uniwersytetu w Bonn: „W cieniu uniwersytetów Bonn, Würzburga i Straßburga, ukształtowała się, niezauważona przez nikogo, jakby nowy front, grupa ludzi złożona $\mathrm{z}$ młodych studentów. Ich hasłem było słowo: liturgia" ${ }^{\prime 5}$. W tymże roku (1912) „Związek katolików z akademickim wykształceniem” (Verein „akademisch gebildeter Katholiken") zorganizował w Düsseldorf spotkanie z odczytami na temat liturgii, które wygłosili Benedyktyni z opactwa Maria Laach: Ildefons Herwegen i Gregor Böckeler. Prasa nie podała wtedy żadnej wiadomości o początkach ruchu, który w niedalekiej przyszłości miał zmienić oblicze Kościoła!

Opactwo benedyktyńskie Maria Laach podjęło się kontynuacji dzieła ruchu liturgicznego zajmując się przede wszystkim formacją środowiska uniwersyteckiego: profesorów i studentów oraz duchowieństwa (w nadziei, że ci ostatni będą dalej rozwijać ideał życia liturgicznego) ${ }^{6}$. W konsekwencji rozpoczęto organizować „dni liturgiczne”, głównie w czasie Wielkiego Tygodnia w opactwie Maria Laach, dla studentów i profesorów. W roku 1913 zebrała się po raz pierwszy na takie spotkanie wprawdzie mała grupa, ale pośród niej znalazły się słynne osobistości, jak Robert Schumann (z Metz), późniejszy premier rządu Francji i protektor jedności Europy, który pisał po latach m.in.: „To spotkanie było dla nas wydarzeniem, wspólnym punktem wyjścia... Już wtedy zaczęliśmy dostrzegać, że to, co toruje drogi porozumienia, jedności i braterstwa, czerpie z tego samego źródła. W tym sensie Maria Laach było kamieniem węgielnym przyszłej Europy"? ${ }^{\text {"W }}$ spotkaniu Wielkiego Tygodnia

${ }^{3}$ B. N e u n h e u s e r, Sto lat ruchu odnowy liturgicznej zapoczatkowanego przez 0. Prospera Guéranger. Przeszlość i perspektywy, RBL 29:1976, s. 195.

${ }^{4} \mathrm{~B}$. N e u n h e u s e r, Movimento liturgico, [w:] Nuovo dizionario di liturgia, red. D. Sartore, A. M. Tr i a c c a, Roma 1984, s. 911.

${ }^{5}$ F. K o l b e, Die liturgische Bewegung, Aschaffenburg 1964, s. 36.

${ }^{6} \mathrm{~B}$. $\mathrm{N}$ e u n h e u s r, Storia della liturgia attraverso le epoche culturali, Roma 1983, s. 140.

${ }^{7}$ F. K o 1 b e, Die liturgische Bewengung..., s. 37. 
1913 roku uczestniczył także Heinrich Brüning, późniejszy niemiecki kanclerz Rzeszy; Paul Simon w przyszłości prepozyt Kapituły katedralnej Paderborn oraz Hermann Platz, który będzie profesorem na uniwersytecie w Bonn. Kilka miesięcy po tym spotkaniu, I. Herwegen, jeden z prelegentów, został opatem w Maria Laach, a z kolei organizator spotkań i odczytów Franz Xaver Münch, został w 1916 roku sekretarzem generalnym Katolickiego Związu Akademickiego (opat Herwegen i Münch współpracowali i wspólnie przyczynili się do tego, że pośród organizacji katolickich Katolicki Związek Akademicki (Katholischer Akademikerverband) stał się prekursorem (pionierem) odnowy liturgicznej w Niemczech ${ }^{8}$.

Opactwo Maria Laach rozpoczęło dzieło kontynuacji ruchu liturgicznego w 1913 roku, kiedy to ,pięciu studentów, młodych ludzi o wysokiej kulturze, przybyło do klasztoru w Maria Laach, jak kiedyś Dante do Fossalta quaerens pacem. Przybywali, aby znaleźć odpowiedź na dręczące wątpliwości, które ich niepokoiły; niezadowoleni z samych siebie i z form pobożności, które praktykowali, prosili o jakieś wartości duchowe, któreby lepiej odpowiadały ich pragnieniom i ,szlyby w parze" z wymaganiami ich duszy. Opat klasztoru wysłał im opatrznościowo ojca Ildefonsa Herwegena, który natychmiast ich zrozumiał, polecił pozostać im dzień w konwencie, wyjaśniając im Msze święta z następnego dnia, pokazując ogniwo łączące wszystkie części, panującego ducha oraz prawdę, która $z$ niej wypływa. Następnego dnia pięciu studentów, w skupieniu mistycznym bazyliki Maria Laach, uczestniczyli w jednej z tych ceremonii liturgicznych, które „umieja” sprawować benedyktyni... i „ich oczy otworzyły się" ku nowej wizji; zrozumieli sprawę najprostszą której wcześniej nie dostrzegali: liturgia może zaspokoić pragnienia ich religijności, usuwa punkty ciemne, które wcześniej sprawiały, że byli niezadowoleni i bierni, daje obiektywną i nadprzyrodzoną podstawę dla ich pobożności, ksztaltuje w nich coś, co nie jest egocentryczne ale Chrystocentryczne"9.

Ildefons Herwegen, po swoim wyborze na opata, zorganizował w Wielkim Tygodniu 1914 roku pierwszy zjazd Katolickiego Związku Akademickiego w Maria Laach, na który przybyło ponad stu profesorów z całych Niemiec. Co prowadziło wykształconych katolików wówczas do Maria Laach? W drugim roku pierwszej wojny światowej H. Platz opublikował artykuł pt. Tęsknota za tym, co organiczne-istotowe $w$ świetle naszej liturgii, w którym wskazal tęsknotę za tym, co Istotowe, co we współczesnej duszy mieszka od dawna, jako szczególna właściwość przeżyć wojennych. „Świat czuje to, co Prawdziwe i Całościowe; wypełnienie tej tęsknoty i czucia sprawia liturgia. Nie ma innej radości równej tej, która wyzwala się przy odkrywaniu ,liturgicznego" Kosmosu. "Ta symfonia słów i tonów, barw i zapachów, znaków i gestów, która... przedstawia najwyższe i najdoskonalsze dzieło sztuki. Atmo-

\footnotetext{
${ }^{8}$ Tamże.

${ }^{9}$ E. C a t $\mathrm{t}$ a n e o, Introduzione alla storia della liturgia occidentale, Roma 1969, s. 423.
} 
sfera liturgii przynosi porządek (ład) i pokój w zamęcie naszego wnętrza, prowadzi do postępującej duchowej stylizacji”,10.

Historia początków ruchu liturgicznego w Kościele niemieckim zaczyna się w opactwie benedyktyńskim Maria Laach (Abbatia S. Mariae ad Lacum), położonym w dolinie, nad największym (2,4 km długości i 1,8 km szerokości) na wyżynie Eifel, jeziorem wypełniającym krater dawnego wulkanu. Klasztor, wybudowany w 1093 r., przechodził różne koleje losu, łącznie z likwidacją opactwa w 1802 r. (decyzją rewolucji francuskiej), które trwało 90 lat. Kongregacja Benedyktyńska Beuron odzyskała Maria Laach w 1892 r. i wkrótce stało się ono sławne w świecie katolickim dzięki takim opatom jak Willibrord Benzler (1893-1902), późniejszy biskup w Metz i Ildefons Herwegen (1913$-1946)^{11}$.

Wspólnota benedyktyńska w Maria Laach wniosła bardzo znaczący wkład przede wszystkim w rozwój życia liturgicznego, a najbardziej znanymi jej przedstawicielami, w okresie międzywojennym, stali się: Ildefons HERWEGEN (1874-1946), Romano GUARDINI (1885-1968), Odo CASEL (1886-1948) i Leo Cunibert MOHLBERG (1878-1963). W prezentowanych rozważaniach zostaną wskazane (w zarysie) najbardziej znaczące działania I. Herwegena i R. Guardiniego, zmierzające ku odnowie życia religijnego poprzez liturgię.

\section{DZIALALNOŚC LITURGICZNA}

OPATA ILDEFONSA HERWEGENA OSB

Ildefons Peter Herwegen przyszedł na świat 27 listopada 1874 r. w Junkersdorf k. Kolonii (Köln), w której ukończył szkołę gimnazjalną, a w Seckau, w Austrii kolegium zgromadzenia zakonnego Oblatów (Zgromadzenie Oblatów Misjonarzy Maryi Niepokalanej). Mając 21 lat wstapił do Zakonu Benedyktynów (OSB) w Maria Laach, po czym studiował w benedyktyńskich uczelniach: Beuron i Anselmianum (Rzym). W roku 1901 przyjął święcenia kapłańskie i kontynuował studia teologiczne na uniwersytecie w Bonn. Od czasu, gdy został opatem (1913) w Maria Laach, rozwinął na jeszcze większą skalę działalność zmierzającą do odnowy życia duchowego w oparciu o liturgię, zwłaszcza w środowiskach akademickich, profesorów i studentów. Rozpoczął od zorganizowania „Dni liturgicznych” w Wielkim Tygodniu 1914 ro$\mathrm{ku}$, będących zarazem pierwszym zjazdem Katolickiego Związku Akademickiego w Maria Laach, na który poza wieloma studentami przybyło ponad stu profesorów z całych Niemiec. Przerażenie, strach i tragizm oraz chaos jakie wdarły się do tego wcześniejszego, wydawało się, w miarę w pokoju żyjącego świata, poprzez wybuch pierwszej wojny światowej, sprawiły, że dla bardzo

${ }^{10}$ F. Kolbe, Die liturgische Bewengung..., s. 37; Autor pisze: „Die Atmosphäre der Liturgie «bringt Ordnung und Frieden in die Verworrenheit unseres Innern», się führt "zu fortschreitender seelischer Stilisierung)" "Tamże.

${ }^{11}$ Th. B o g l e r, Abteikirche Maria Laach, München u. Zürich 1975, s. 2 n. 
wielu ludzi wpływ monastycyzmu benedyktyńskiego i ich odnowionej liturgii, okazał się bardzo pomocny i skuteczny. Opat I. Herwegen rozwiną w tym względzie bogatą działalność pisarska, ale stał się przede wszystkim mistrzem mówionego słowa, poprzez wykłady, referaty i homilie. Jego pisma dotyczyły życia monastycznego, które uważał za istotną formę życia Kościoła, mające swoje źródło w Duchu Świętym. Sprawy życia duchowego wiązał bardzo mocno z Kościołem i liturgią którą uznał za podstawowy przejaw obecności Ducha Świętego w Kościele i za źródło życia duchowego ${ }^{12}$. Znamienne dla poglądów opata Herwegena było przekonanie wyrażone w jednym ze swych pism, iż duchowa przemiana musi być zakotwiczona w Mistycznym Ciele Chrystusa i Liturgii ${ }^{13}$. Jak wszyscy zwolennicy i pionierzy ruchu liturgicznego, I.Herwegen był przekonany, że odnowa liturgiczna będzie prowadzić do głębokich zmian wszystkich dziedzin życia Kościoła w Duchu Chrystusowym.

I. Herwegen zajmował krytyczny stosunek do Republiki Weimarskiej w Niemczech, gdyż, jego zdaniem, przyczyniła się ona do obniżenia autorytetu państwa i rodziny. To właśnie skłoniło go do poparcia działań zmierzających do „uzdrowienia narodu” podjętych przez A. Hitlera; po wielu jednakże późniejszych, bardzo negatywnych, doświadczeniach przeszedł w 1935 roku do opozycji ${ }^{14}$.

Jako opat w Maria Laach, Ildefons Herwegen OSB zainicjował serię monografii, z których najważniejszymi są: Beiträge zur Geschichte des alten Mönchtums und Benediktinerordens, I-XXI (Münster 1912-1941) oraz zainicjowana w 1918 roku popularna seria liturgiczna Ecclesia orans, I-XXII (Freiburg 1918-1948). W 1931 roku założył Herwegen w opactwie Maria Laach „Benediktiner-akademie" do badan i studiów nad liturgią i monastycyzmem (od roku 1948 nosi ta instytucja nazwę: Abt-Herwegen-Institut) ${ }^{15}$.

Do najważniejszych prac I. Herwegena należa ponadto: $\mathrm{w}$ dziedzinie problematyki zakonnej: Geschichte der benediktinischen Professformel (Münster 1912-1937); Sinn und Geist der Benediktinerregel (Einsiedeln 1944); w dziedzinie sztuki i liturgii: Das Kunstprinzip in der Liturgie (Paderborn 1912-1920); Christliche Kunst und Mysterium, (Münster 1929); z dziedziny hagiografii: Der heilige Benedikt. Ein Charakterbild (Düsseldorf 1917-1951); Kirche und Seele. Die Seelenhaltung des Mysterienkultes und ihr Wandel im Mittelalter (Münster 1926-1928); Antike, Germanentum und Christentum" (Salzburg 1931). Zbiory artykułów I. Herwegena ukazały się pt. Alte Quellen neuer Kraft (Düsseldorf 1920-1922); Lumen Christi. Gesammelte Aufsätze (München 1924); Von christlichen Sein und Leben (Berlin 1931-1940) ${ }^{16}$.

I. Herwegen jako opat Maria Laach stanał od początku po stronie teologicznych poglądów swego współbrata Odo Casela (1886-1948); jego zasługa

${ }^{12}$ Zob. F. K ol b e, Die liturgische Bewengung..., s. 38; J. S t e fań s k i, Herwegen I., [w:] EK t. 6, Lublin 1993, s. 807.

${ }_{13}$ Zob. F. K o I b e, Die liturgische Bewengung..., s. 38.

${ }^{14}$ Por. J. Stefański, Herwegen I..., s. 807.

${ }^{15}$ Tamże.

${ }^{16}$ Tamże. 
polegała na przygotowaniu „gruntu” i stworzeniu takiej atmosfery, w której mogła być przyjęta i wzrastać „Mysterienlehre" (nauka o misterium) Odo Casela.

W roku 1917 r. opat Herwegen zdecydował opublikować artykuły o tematyce liturgicznej, młodego kapłana o nazwisku Romano Guardini (1885-1968); niestety, po różnych niepowodzeniach, udało się dopiero w 1918 roku wydać niewielką jego książkę pt. Vom Geist der Liturgie ( $O$ duchu liturgii). Zyskała ona w ciagu minionych dziesięcioleci duże uznanie, czego dowodem są liczne wydania i tłumaczenia na wiele językó ${ }^{17}$; wtedy jednakże wydawca był zdania, że taka literatura, jak ta, nie znajdzie czytelników ${ }^{18}$. Opat Ildefons Herwegen, pod data „Święta Wielkanocy 1918 r." napisał „słowo wprowadzenia”, w którym m.in. zwrócił uwagę na fakt, iż „liturgię nazwano wielkim „katechizmem świeckich”.Tak było w pierwszych wiekach Kościoła. Jeżeli chcemy,aby tak się znów stało, musimy w wychowaniu rodzinnym, w szkole, na kazaniu o wiele więcej, niż to miało miejsce dotąd wskazywać na religijne wartości duchowe i siły wychowawcze, które właśnie znajdują się w katolickiej liturgii i odnajduja punkty styczne w niemieckim usposobieniu i w duszy. I takie dążenia chce popierać nasza seria wydawnicza Ecclesia orans, aby poprzez opracowywanie liturgicznych pojęć, działań i tekstów, służyć poznaniu i głębszemu zrozumieniu liturgii przez szerokie kręgi duchowieństwa, nauczycielstwa i wykształconego świata świeckich. (...) Jako cel postawiliśmy sobie udostępnić, otworzyć bogate skarby liturgii do wykorzystania w życiu religijnym. W przedkładanym Czytelnikom pierwszym tomiku, którym otwieramy naszą serię, Guardini pokazuje, jak bardzo - poprawnie zrozumiana liturgia odpowiada zasadom, także czysto naturalnym, zdrowej psychologii i kulturze duchowej. (...) Autor, mając na uwadze bardziej konkretnego człowieka i jego „zdolność liturgiczna” aniżeli naukowość, chce przygotować przyjazny grunt, uczynić duszę człowieka bardziej usposobioną na przyjęcie tego, co nagromadzone jest w liturgii”".

Książeczka R. Guardini zapoczątkowała zatem serię wydawniczą Ecclesia orans. Zur Einführung in den Geist der Liturgie (Kościót modlacy się. Wprowadzenie do ducha liturgii). W następnych latach ukazały się dzieła, które należą do trwałych świadectw liturgicznej odnowy, jak Odo Casela: Das Gedächtnis des Herrn in der altchristlichen Liturgie i Die Liturgie als Mysterienfeier; Alberta Hammenstede, przeora Maria Laach: Die Liturgie als Erlebnis; Atanasiusa Millera: Die Psalmen, Einführung und Übersetzung; jezuity Josefa Krampa, wyjaśnienie formularzy mszalnych pt. Meßliturgie und Gottes reich (3 tomy); Antona Baumstarka Vom geschichtlichen Werden der Liturgie oraz Johanna Petera Kirscha: Die Stationskirchen des Missale Romanum ${ }^{19}$. Ta seria służyła nie tylko wiedzy, lecz także rozszerzaniu idei liturgicznych.

Od roku 1918 zaczęły się ukazywać, głównie pod kierownictwem Kuniberta Mohlberga: Liturgiegeschichtlichen Quellen und Forschungen; do1939

${ }^{17} \mathrm{~W}$ języku polskim ukazała się dopiero po prawie 80-u latach: R. G u a r d i n i, O duchu liturgii, Kraków 1996.

${ }^{18}$ F. K o l b e, Die liturgische Bewegung..., s. 38.

19 Tamże, 39. 
roku ukazało się 31 zeszytów, a po wojnie podjęto kontynuację tego pisma. Dużą zasługę w ogarnianiu dalszych kręgów wiernych problematyką i sprawami liturgii miała książka dla ludu: Die betende Kirche ${ }^{20}$.

Opat Ildefons Herwegen przeszedł $\mathrm{z}$ tego świata na liturgię niebiańską sprawowaną w świętym mieście Jeruzalem, 2 września 1946 roku w Maria Laach.

\section{ROMANO GUARDINI A RUCH LITURGICZNY W NIEMCZECH}

Romano Guardini urodził się 17 lutego 1885 roku we włoskiej miejscowości Isola Vicentina k. Werony. W następnym roku jego ojciec, przemysłowiec, został mianowany konsulem Włoch i wraz $\mathrm{z}$ całą rodziną przeniósł się do Mainz (Moguncji). W ten sposób ojczyzną Guardiniego, nie z krwi ale $\mathrm{z}$ wyboru, stały się Niemcy, co jeden z biografów, Helmut Kuhn, skomentował: „On jest nasz - możemy powiedzieć $z$ wdzięcznością, która uznaje jednocześnie słuszne pretensje włoskiej ojczyzny"21. Łączność Romano Guardini $\mathrm{z}$ dwoma narodami o odmiennej kulturze, umysłowości i temperamencie stanowi istotny element dla zrozumienia jego życia oraz twórczości.

R. Guardini po ukończeniu gimnazjum w Moguncji rozpoczął studia (1904) na uniwersytecie w Monachium nie mając jednakże do końca sprecyzowanego kierunku studiów. Najpierw studiuje nauki przyrodnicze, potem chemię, medycynę i ekonomię polityczną; te ciagłe zmiany kierunków uczelni pozwoliły mu poznanie środowisk uniwersyteckich Monachium, Tybingi i Berlina, w którym przeżył (1905r.) kryzys religijny, a jego owocem była świadomość powołania go przez Boga do kapłaństwa ${ }^{22}$. Decyzję poświęcenia się na służbę Bogu i bliźnim w stanie kapłańskim, pomimo pewnej niechęci ze strony ojca, Guardini skomentował słowami: „Chciałem być tam, gdzie jest większa możliwość miłości”, ${ }^{23}$. Studia teologiczne odbywał Guardini na uniwersytecie we Fryburgu Badeńskim (Breisgau) i Tybindze, a następnie w Moguncji (Mainz) (Wyższe Seminarium Duchowne), gdzie 25 maja 1910 roku otrzymał święcenia kapłańskie.

R. Guardini przez pierwsze dwa lata po święceniach petnil posługe wikariusza w Moguncji, poświęcając się w sposób szczególny pracy z młodzieżą. Od 1912 roku kontynuował studia teologiczne w Tybindze uwieńczone w 1915 r. doktoratem. ${ }^{24}$ Po uzyskaniu doktoratu R.Guardini pracował znowu,

${ }^{20}$ Tamże.

${ }^{21}$ J. G r ześ ś o w i a k, Romano Guardini. Życie $i$ wktad $w$ odnowę liturgii, „Homo Dei" (dalej: HD) 38 (1969), s. 123 n.; dane biograficzne zob. M. W o 1 i c k i, Stowo o Autorze, [w:] R. G u a r d in i, O duchu liturgii..., s. 12.

${ }_{22}$ Zob. M. J a w or s k i, O tej ksiażce i jej autorze (Przedmowa do ksiąziki R. G u a r d i n i, Koniec czasów nowożytnych, Kraków 1969, s. 6; M. W o l i c k i, Słowo..., s. 13.

${ }^{23}$ M. Wol i c k i, Stowo..., s. 13.

${ }^{24}$ M. Jaworski o tym doktoracie mówi, że ,rozprawa była poświęcona teologii świętego Bonawentury. Studia te miały decydujące znaczenie: Guardini nawiąże w całej swej twórczości naukowo-publicystycznej - poprzez franciszkańskiego Doktora Kościoła - do chrześcijańskiego 
przez kolejne pięć lat, jako wikariusz w Moguncji, włączając się - w działalności dusžpasterskiej - w ,pehny nuirt" odnowy liturgicznej $i$ oddając się $w$ tej dziedzinie pracy wśród młodzieży, zwłaszcza akademickiej. Praca duszpasterska w określonych kręgach i środowiskach będzie dla $R$. Guardini tak ważna i decydująca, że poświęci jej nie tylko prawie wszystkie miesiące wakacyjne, ale będzie także dla niego natchnieniem determinującym całą jego działalność pisarskąa 25 .

W 1920 roku R. Guardini uzyskuje habilitację z dogmatyki katolickiej, a dwa lata później tytuł prywatnego docenta na Wydziale Teologii Katolickiej uniwersytetu w Bonn. W roku 1923 Guardini zostaje profesorem Wydziału Teologii Katolickiej na uniwersytecie we Wrocławiu, tworząc jednocześnie na prośbę ministra kultury C. H. Beckera - katedrę filozofii religii i światopoglądu chrześcijańskiego na uniwersytecie im. Humboldta w Berlinie, dokąd dojeżdża z wykładami. Guardini kieruje tạ katedra przez 15 lat (1923-1939), a jego berlińskie wykłady, zapowiadane nawet przez prasę, ściagały licznych słuchaczy, zarówno katolików jak i protestantów ${ }^{26}$. Jednocześnie, wraz ze swymi przyjaciółmi, Guardini wydaje czasopismo „Schildgenossen”, w którym na bieżąco publikuje wiele ze swoich myśli, co sprawia, że z latami umacniania się władzy hitlerowskiej, działalność Guardiniego, wychodząca niejednokrotnie daleko poza ramy czysto akademickiego nauczania, staje się dla władz Trzeciej Rzeszy coraz bardziej niewygodna. W latach terroru politycznego i dyskryminacji rasowej, człowiek głoszacy ideały wolności, prawa i obowiazki osoby, musiał stanać w wyraźnej opozycji do panującego wówczas w Niemczech oficjalnego nurtu ${ }^{27}$. Na jesieni 1939 roku R. Guardini zostaje zmuszony przez reżim narodowo-socjalistyczny do odejścia $\mathrm{z}$ katedry uniwersyteckiej, ale mimo grożących niebezpieczeństw nie rezygnuje z nauczania prywatnie, organizując swego rodzaju uniwersytet ludowy. W tym samym czasie, w jezuickim kościele w Berlinie, głosi w drugi wtorek każdego miesiąca swoje nauki, które gromadzą elitę katolicką stolicy Niemiec ${ }^{28}$. Jednakże coraz bardziej nasila się terror tajnej policji-gestapo, co sprawia, że latem 1943 roku Guardini opuszcza Berlin i udaje się do małej parafii Mooshausen w Szwabii, do swego przyjaciela proboszcza $M$. Józefa Weigera, u którego pozostaje do końca wojny.

W 1945 roku R. Guardini powraca do pracy uniwersyteckiej, obejmując katedrę światopoglądu chrześcijańskiego w Tybindze. Trzy lata później, w roku 1948 przenosi się do Monachium, gdzie pracuje, mimo podeszłego wieku, do 1963 roku; po przejściu na emeryturę jego następcą na katedrze dogmatyki zostaje Karl Rahner.

nurtu takich myślicieli jak św. Augustyn i św. Anzelm z Canterbury. Jest to nurt platońsko-augustyński, który - jak on sam go charakteryzuje - w przeciwieństwie do obiektywistycznego nurtu arystotelesowskiego takich myślicieli jak św. Albert Wielki, św. Tomasz z Akwinu i Duns Szkot, nie dorównuje tamtemu pod względem precyzji myśli, nacechowany jest natomiast większą głębią serca" - M. J a w o r s k i , O tej ksiazzce..., s. 6.

${ }^{25}$ Tamże.

${ }^{26}$ Zob. M. Wol i ck i, Stowo..., s. 16 n.

${ }^{27}$ M. J aw or ski, O tej ksiażce..., s. 7.

${ }^{28}$ Tamże. 
Romano Guardini równolegle z pracą duszpasterską i działalnością uniwersytecką łączył swoją twórczość naukową którą rozpoczął pracą doktorską dotyczącą nauki św.Bonawentury o Odkupieniu (Die Lehre des hl. Bonaventura von der Erlösung. Ein Beitrag zur Geschichte und zum System der Erlösungslehre,Düsseldorf 1921) i filozoficznym traktatem o przeciwieństwach (Der Gegensatz. Versuche zu einer Philosophie des Lebendig-Konkreten, Mainz 1925). Te pierwsze prace stanowią drogowskaz dalszej, niezwykle bogatej i różnorodnej w treści i formie, twórczości literackiej Guardiniego w dziedzinie teologii, filozofii, liturgii i poezji ${ }^{29}$. „Romano Guardini ciagle żył wyznawaną wiara, był przepełniony niejako rzeczywistością wiary i Bożego Objawienia w dziele stworzenia i w Kościele żyjącym w Chrystusie. Był człowiekiem przez całe życie pilnie i żarliwie poszukującym prawdy oraz ciagle pytającym. Stąd też stale wyrastały przed nim problemy i trudności, na które z całą pasją szukał odpowiedzi. Był chrześcijaninem głęboko zaangażowanym w sprawy wiary i w sprawy świata, głęboko wierzącym, ale niejednokrotnie i wattpiącym, a przede wszystkim - ciagle pytającym. (...) Był chrześcijaninem świadomym trudnej problematyki wiary, a przy tym chrześcijaninem ufajacym. $Z$ tej właśnie egzystencjalnej potrzeby poznania prawdy, znalezienia odpowiedzi na najistotniejsze pytania wyrosła cała twórczość teologiczna i filozoficzna Romano Guardiniego"30.

Twórczość pisarską i publicystyczną R. Guardiniego grupują teologowie wokół czterech podstawowych tematów chrześcijaństwa: światopogląd chrześcijański (wiara), osoba Jezusa Chrystusa i dzieło Odkupienia, misterium (tajemnica) Kościoła i liturgia. Tematy te nie występowały oczywiście oddzielnie od siebie, w różnych okresach życia i twórczości Guardiniego, ale raczej przenikały się wzajemnie i nieustannie jako nurty skupiające życie duchowe, sferę przemyśleń, uczuć, pragnień i dążeń autora ${ }^{31}$.

Problematyką światopoglqdu chrześcijańskiego zajął się od strony naukowej Guardini gdy został powołany do Berlina na nowo powstającą taka katedrę i kiedy trzeba było zbierać materiały, poszukiwać metody i rozwijać zasady. „Do wypełnienia tego zadania konieczna była nieustanna konfrontacja wiary z rzeczywistością świata i życia i odczytywanie świata wciąż na nowo w świetle wiary"32. Określając światopogląd chrześcijański uważał, że jest to stałe, metodyczne spotkanie między wiarą a konkretnym światem kultury, historii, życia społecznego itd. Takie żywe spotkanie wiary z życiem i światem dostrzegał R. Guardini w poezji i literaturze; stąd też wyrosły jego dzieła dotyczące słynnych postaci $\mathrm{z}$ dzieł poetyckich oraz analiza psychologicznoteologiczna postaci z powieści Dostojewskiego ${ }^{33}$.

\footnotetext{
${ }^{29}$ M. Wolicki, Stowo..., s. 18.

${ }^{30}$ Tenże, s. 19 n.

${ }^{31}$ Tenże, s. 20.

${ }^{32}$ Tamże, s. 21.

${ }^{33}$ Tamże, s. 21 . O twórczości pisarsko-publicystycznej R. Guardiniego pisze bardzo szeroko J. M i s i u r e k, Guardini R., [w:] EK, t. 6, Lublin 1993, kol. 369-372.
} 
Osoba Jezusa Chrystusa i dzieto Odkupienia - jako centralny temat chrześcijaństwa stanowiły główny i szczytowy punkt twórczości R. Guardiniego, któremu poświęcił on największy wysiłek i najwyższy wkład swojej twórczości.W całej swej twórczości naukowej i publicystycznej jak i w działalności duszpasterskiej, zwłaszcza na ambonie i w spotkaniach z młodzieża, chodziło Guardiniemu o budzenie, pogłębianie i umacnianie wiary; to właśnie uważał za motyw przewodni swego życia kapłańskiego ${ }^{34}$. Książka o Chrystusie (Der Herr. Betrachtungen über die Person und das Leben Jesu Christi, Würzburg 1937), powstała z kazań, stała się centralnym i szczytowym dziełem jego twórczości.

Misterium (tajemnica) Kościola - jako wspólnota wszystkich ludzi ochrzczonych i wierzących w Chrystusa - stanowiło dalsze epokowe osiagnięcie R. Guardiniego, wyprzedzające o wiele lat naukę Soboru Watykańskiego II. Autor $\mathrm{z}$ całym przekonaniem stwierdzal, że droga do Chrystusa prowadzi przez Kościół; pisząc o misterium (tajemnicy) Kościoła Guardini powołuje się na swoje osobiste przeżycia, i dlatego potrafi z taką pasją przekonywać innych ${ }^{35}$. Kościół poręcza autentyczne rozumienie osoby Jezusa Chrystusa i wiarę w Niego, a Chrystus sam jest w Kościele ukryty, przez niego przemawia i działa mocą Ducha Świętego. Dla Guardiniego, jako Włocha z pochodzenia i kapłana, podobnie jak i dla jego przyjaciół, słuchaczy i czytelników, Kościołem był przede wszystkim Kościół rzymsko-katolicki ${ }^{36}$.

R. Guardini interesował się i zajmował liturgią od początku swego życia kapłańskiego, zarówno w działalności duszpasterskiej jak i w obszernej twórczości pisarskiej i publicystycznej. Pierwszym opracowaniem z zakresu liturgii jest $O$ duchu liturgii (Vom Geist der Liturgie, 1918); następnym artykuł z 1921 roku Über die systematische Methode in der Liturgiewissenschaft (JLW 1921, 97-108). W 1923 roku ukazuje się pozycja dotycząca wychowania liturgicznego Liturgische Bildung, wydana w Burg Rothenfels, z którego Guardini zamierzał uczynić nowe centrum odnowy liturgicznej w Niemczech. W tym samym roku ukazuje się inna znamienita książka R. Guardiniego pt. Znaki święte (Von heiligen Zeichen, Mainz 1923).

Dalsze prace R. Guardiniego z zakresu liturgii koncentrują się głównie wokół zagadnień związanych $\mathrm{z}$ uczestnictwem we Mszy św. i z modlitwa. W 1930 r. ukazuje się książa Gemeinschaftliche Andacht zur Feier der heiligen Messe (Düsseldorf), a w roku 1939 Besinnung vor der Feier der hl. Messe (Mainz). W roku 1940 R. Guardini wydaje kilka pozycji z zakresu modlitwy liturgicznej: Die Anbetung (Würzburg), Über das Rosenkranzgebet (Colmar), Ein Wort zur liturgischen Frage (Colmar). W 1942 roku w czasopiśmie „Gottesdienst" pisze artyku\}: Die mystagogische Predigt: Volksliturgie und Seelsorge. W latach powojennych zaczęto wznawiać $O$ duchu liturgii, Znaki święte i wiele innych pozycji.

\footnotetext{
${ }^{34}$ M. W ol i c k i, Stowo.., s. 23.

${ }^{35}$ Tamże, s. 26.

${ }^{36}$ Tamże, s. 27.
} 
Czas Soboru Watykańskiego II stał się nowym bodźcem dla Guardiniego do twórczości w dziedzinie liturgii; gdy w 1964 roku zebrał się III Kongres Liturgiczny w Moguncji, Guardini napisał z tej okazji list pt. Akt kultu $i$ obecne zadanie wychowania liturgicznego (Der Kultakt und die gegenwärtige Aufgabe der liturgischen Bildung. Ein Brief) W liście Guardini podkreśla znaczenie pracy nad odnowieniem liturgii, pod którą położył podwaliny Sobór oraz zajmuje się sprawą aktu liturgicznego, który powinien obejmować nie tylko duchowe wnętrze, ale człowieka jako całość: jego ciało i ducha oraz uwzględniać wymiar wspólnotowy, jako że każdy wierzacy żyje we wspólnocie parafialnej, w której jest obecny Kościół. Potrzeba odpowiedniego nauczania i wychowania, także w zakresie spełniania aktu liturgicznego, aby zostały zrealizowane postulaty Vaticanum II.

W roku 1966 ukazało się dzieło zbiorowe Guardiniego, podsumowujące u kresu jego życia dorobek liturgiczny pt. Liturgia i liturgiczne wychowanie (R. Guardini, Liturgie und liturgische Bildung, Würzburg 1966), w którym został zamieszczony wyżej wspomniany list.

Dokonane krótkie resumé dorobku liturgicznego R. Guardiniego pokazuje jak wiele uwagi i troski poświęcał on zrozumieniu istoty liturgii i właściwego wychowania liturgicznego. R. Guardini bardzo doceniał rolę liturgii w całym życiu chrześcijańskim i życiu Kościoła, widząc w niej to, co Sobór Watykański II określił jako „fons et culmen” (,źródło i szczyt”: $K L 10$ ).

„Całość dorobku Guardiniego jako myśliciela i teologa jest imponująca i obejmująca wiele dziedzin. Świadczy ona o żywym zaangażowaniu autora w życie Kościoła i w egzystencjalne problemy ludzi sobie współczesnych. Ukazuje ona zarówno głębię jego myśli jak i dalekowzroczność jego spojrzenia, przechodzącą niemal w profetyczność, 37 .

Romano Guardini na wiele lat przed Soborem Watykańskim II stał się jednym z jego najważniejszych prekursorów, wnosząc wielki wkład zwłaszcza w dwóch dziedzinach: w soborową naukę o Kościele i w dzieło Soboru odnowy liturgii.

Dogłębne ujęcie sensu i istoty Kościoła przedstawił Guardini sam tworząc autentyczne wspólnoty chrześcijańskie, zwłaszcza w czasach duszpasterzowania wśród studentów. Guardini postawił osobę Jezusa Chrystusa w centrum swego życia i działania; słynne jest jego powiedzenie, że "Chrystus przemawia do nas nie jako odosobniona postać, ale jako Kościół, ’38. Papież Paweł VI postawił także w centrum prac soborowych Chrystusa, o którym mówił na otwarcie drugiej sesji Soboru, że ,jest naszym punktem wyjścia. Chrystus jest naszym Przewodnikiem i Drogą. Chrystus jest naszą nadzieja i naszym celem... Nie szukajmy żadnej innej prawdy jak tylko Słowa Pana, naszego jedynego Nauczyciela"39.

R. Guardini wniósł także wielki wkład w soborowe dzieło odnowy liturgii; chociaż nie brał osobiście udziału w pracach Soboru, to jednak jego

\footnotetext{
${ }^{37}$ M. W o l i c k i, Stowo..., s. 30.

${ }^{38}$ Tamże, s. 31.

${ }^{39}$ Tamże.
} 
uczniowie i przyjaciele, jako członkowie soborowej Komisji Liturgicznej przyczynili sie w dużym stopniu do opracowania Konstytucji o Liturgii.

Po śmierci R. Guardiniego, która nastapiła 1 października 1968 roku, w 83 roku jego życia, papież Paweł VI w depeszy kondolencyjnej podkreślił ,jego pełną zasługi działalność jako uczonego i jako pisarza, zmierzającą do lepszego zrozumienia prawd teologicznych i ukształtowania prawdziwej pobożności liturgicznej;"40

Romano Guardini należy do tych teologów, którzy w swoim życiu potrafili umiejętnie połączyć wiedzę teologiczną z praktyką życia chrześcijańskiego, a zwłaszcza $\mathrm{z}$ modlitwą i sprawowaniem liturgii. W jego życiu i działalności duszpasterskiej oraz publicystycznej liturgia zawsze zajmowała miejsce wyjątkowe, jeśli nie pierwszorzędne; stanowiła przedmiot jego ciągłego zainteresowania i troski, które towarzyszyło mu przez całe życie kapłańskie. „Właściwie pierwszym rozdziałem jego życiowej, publicznej działalności, mającym najbardziej widoczne konsekwencje, była właśnie liturgia, czynne $i$ całkowite włączenie się od pierwszych lat pracy duszpasterskiej w ruch liturgicznej odnowy" ${ }^{\prime \prime}$. Guardini podkreślając rolę w liturgii: żywej postaci, ręki, kroku, gestu, symbolu, elementu dramatycznego - co miało wielki wpływ na młodych ludzi, wśród których pracował - „stał się i pozostał dobrym duchem ruchu liturgicznego" ${ }^{, 2}$. R. Guardini wykazywał, że ruch liturgiczny ma na uwadze całego człowieka, „który z sercem i duchem, z ciałem i dusza staje przed Bogiem w czynności i modlitwie liturgicznej i wielkie formy przeszłości wypełnia nowym życiem,43.

Romano Guardini przedstawił swoje poglądy liturgiczne w bogatej działalności publicystycznej, spośród której należy zwrócić uwagę na: „O duchu liturgii” (Vom Geist der Liturgie, 1918), „Znaki święte” (Von heiligen Zeichen, 1923), „Przedszkole modlitwy” (Vorschule des Betens, 1943).

\section{O duchu liturgii}

Książka R. Guardiniego Vom Geist der Liturgie ukazała się jako pierwsze jego dzieło liturgiczne w 1918 roku, z przedmową opata z Maria Laach Ildefonsa Herwegena; rozpoczynała ona serię wydawniczą „Ecclesia orans".

„O duchu liturgii” składa się z siedmiu rozdziałów, z których każdy omawia istotny element liturgii jak: modlitwę liturgiczna, wspólnotę, styl i symbolikę liturgiczną - te cztery pierwsze rozdziały mają charakter filozoficzno-teologicznego fundamentu, na którym autor przedstawia: liturgię jako świętą grę, powagę liturgii i zagadnienie prymatu Logosu nad Etosem. Ujmując liturgię jako całość, Guardini daje się niejako porwać jej urokowi, powadze i potędze; ukazuje się nam „dusza prawdziwego artysty wysokiej klasy,

\footnotetext{
${ }^{40}$ J. G r z eśs ow i ak, Romano Guardini. Życie i wkład..., s. 123.

${ }^{41}$ M. Wol i cki, Stowo..., s. 35.

${ }^{42}$ W. D irk s, Romano Guardini, [w:] Ökumenische Menschen, Leipzig 1969, s. 83,
} cyt. za: M. W o li c k i, Stowo..., s. 36.

${ }^{43}$ M. W o 1 i c k i , Twórczość teologiczna Romano Guardiniego, HD 50 (1981) n.4, s. 298. 
co uwidacznia się i w barwnym stylu, pełnym najkunsztowniejszych zwrotów i w obficie rozsianych porównaniach, zaczerpniętych $\mathrm{z}$ dziedziny poezji i sztuki" ${ }^{\prime 4}$.

\section{Modlitwa liturgiczna}

R. Guardini uważa, że pośród dwóch form modlitwy: liturgicznej i płynącej z pobożności ludu wierzącego, modlitwa „nieliturgiczna” powinna się wzorować na modlitwie liturgicznej, która jest całkowicie przepojona bogactwem prawdy objawionej. W liturgii „lex orandi” - zasada modlitwy jest według starego powiedzenia równocześnie „lex credendi” - zasadą wiary. W modlitwach liturgicznych ukazuje się cała pełnia prawd objawionych, ale do głosu dochodzi też i uczucie, które sprawia, że taka modlitwa jest żywą w modlitwach liturgicznych pulsuje bogate życie uczuciowe, jak choćby w psalmach, ale uczucia te są kontrolowane przez rozum i pełne powściagliwości. Dla Guardiniego wzorem wszystkich modlitw jest modlitwa brewiarzowa odmawiana w chórze, ale liturgia nie używa tego sposobu modlitwy często. „Liturgia używa raczej, jako zasadniczej postaci, wspólnej modlitwy, formy dramatycznej. Dzieli ona obecnych na dwa chóry i pozwala rozwijać się modlitwie w formie wezwań $\mathrm{i}$ odpowiedzi. Wprowadza ona całość $\mathrm{w}$ stan dynamiczny i utrzymuje w nim, ponieważ każdy jest zmuszony do częściowej przynajmniej uwagi, każdy wie, że od niego zależy dalsze rozwijanie się wspólnej modlitwy"45. Guardini jest zdania, że całe wieki pobożności, która rozwinęła się w Kościele, stworzyły bogaty dorobek kulturowy liturgii, wchodzący w skład kultury ogólnoludzkiej. Liturgia uświadamia nam, że „wiele stuleci pracowało tu i dało swój najlepszy wkład. Wykształcone słowo, w różnoraki sposób rozwinięty świat pojęć i myśli, w różnorodną piękność rozwinięte sposoby kompozycji, począwszy od krótkich wezwań i misternej struktury modlitwy aż do kunsztownej postaci brewiarza lub Mszy św. - wszystko ściśle złączone z całym dziełem roku kościelnego. Oddziaływują na siebie wzajemnie formy czynne, narracyjne, śpiewane. Wciąż zmienia się styl poszczególnych części: jasny i prosty oficjum, tajemniczo-bogaty świąt Matki Bożej, pełne uroku oficja wczesnochrześcijańskich Męczennic-Dziewic. Dodajmy do tego jeszcze cały zakres gestów i czynności, naczynia, przedmioty kultu i szaty, dzieła sztuki architektonicznej, malarskiej i rzeźbiarskiej, śpiew i grę organową. W tym wszystkim tkwi ważna nauka dla życia duchowego. Religia potrzebuje kultury. Przez to pojęcie „kultura” rozumiemy całokształt tych wartości, jakie wytwarza twórcza, kształtująca, porządkująca moc ludzka: wiedza, sztuka, ustawy społeczne itd. Ten skarbiec prawd, instytucji, czynności duchowych, które Bóg przekazał ludziom przez swoje Objawienie, kultura ma za zadanie wytrwałą pracą otworzyć, wydobyć jego zawartość i zastosować do życia w jego różnorodnych formach" ${ }^{\text {"46 }}$. Kultura i religia wzbogacają się wzajemnie, dlatego Kościół zawsze był obrońcą prawdziwej, szlachetnej kultury.

\footnotetext{
${ }^{44}$ M. W o 1 i c k i, Stowo..., s. 37 n.

${ }^{45}$ R. G u a r d i n i, O duchu liturgii, Kraków 1996, s. 66.

${ }^{46}$ Tamże, s. 68.
} 
Kulturą, która nie staje się natrętna, ale leży w wewnętrznej dyscyplinie myśli, woli i uczucia, powinna być przesycona modlitwa, która ,powinna być zdrowa, prosta i mocna. Musi ona pozostać w łączności z rzeczywistością i nie może się obawiać nazwania rzeczy po imieniu. Człowiek powinien odnaleźć w swojej modlitwie pełnię swego życia. Z drugiej strony powinna ona być pełna myśli i mocnych obrazów, powinna mieć rozwinięty i zarazem dobrze opanowany język, powinna być jasna, przejrzysta w budowie, zrozumiała dla prostego człowieka, a dla wykształconego - pobudzająca i pokrzepiająca,47.

\section{Wspólnota liturgiczna}

R. Guardini uważa, że podmiotem liturgii nie jest jednostka, ale wspólnota: „liturgia nie mówi «Ja», lecz «My» (...) liturgia jest sprawowana nie przez jednostkę, lecz przez wspólnotę wiernych. A ta wspólnota składa się nie tylko z tych ludzi, którzy właśnie są w kościele (...) ta wspólnota wykracza poza granice określonej przestrzeni i obejmuje wszystkich wiernych na całej ziemi. Przenika ona również poza granice czasu, gdy modląca się na ziemi wspólnota łączy się ze zmarłymi, którzy znajdują się w wieczności. Nawet określenie „wszechświat” nie wyczerpuje jeszcze liturgicznego pojęcia wspól-

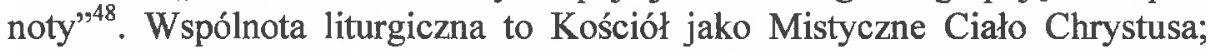
dlatego doświadczenie wspólnoty Kościoła jest możliwe przede wszystkim w liturgii. Poszczególny wierny w liturgii ,widzi siebie nie jako odrębną istotę, lecz jako członka tej wspólnoty stojącej w obliczu Boga. Ona jest tą, która przemawia do Boga; każdy wierny mówi do niej. Od niego żąda ona, by czuł się jej członkiem i by chciał nim być. Przeżycie wspólnoty Kościoła przez jednostkę mieści się na płaszczyźnie liturgicznej. Wierzący - jeżeli tylko chce uczestniczyć w liturgii w sposób żywy - musi sobie uświadomić, że jest członkiem Kościoła i że w nim Kościół święty się modli i działa; musi on ze wszystkimi innymi wiernymi $w$ tej wyższej jedności jedno wiedzieć $\mathrm{i}$ chcieć być jedno $\mathrm{z}$ nimi ${ }^{\text {’49 }}$. Istnieje niewątpliwie trudność dotycząca stosunku jednostki do wspólnoty, dlatego wspólnota duchowa , tak jak każda inna, wymaga od jednostki dwóch warunków: ofiary i zadania. Ofiary rozumianej jako rezygnacja $\mathrm{z}$ tego wszystkiego, co byłoby we wspólnocie tylko dla jednostki, a wyłączałoby innych; jednostka musi ofiarować wspólnocie część swojej niezależności i samostanowienia ${ }^{50}$. Od jednostki wymaga się ponadto: zadania, tzn. aby przyjęła bogatszą treść życia wspólnoty jako własną, aby się w niej poszerzyła, włączyła ja do swej świadomości, potwierdziła i wypełniła ${ }^{51}$. Podejmując ofiarę i zadanie jednostka we wspólnocie będzie mogła postępować za zamiarami i drogami liturgii: „modlić się wspólnie, zamiast samemu decydować o modlitwie; słuchać, zamiast dowoli sobą decydować; dostosować się

\footnotetext{
${ }^{47}$ Tamże, s. 70

48 Tamże, s. 71.

49 Tamże, s. 72 n.

50 Tamże, s. 73.

51 Tamże, s. 73
} 
do porządku, zamiast postępować według własnej woli" ${ }^{\text {"52 }}$. Guardini uważa, że jednostka we wspólnocie liturgicznej nie „rozpływa się" w całości; jest w nia włączona, ale tak, że całkowicie zostaje tym czym jest: samodzielna, autonomiczną osobowością. "To znajduje swój wyraz szczególnie w tym, że połączenie członków między sobą nie idzie bezpośrednio od jednego człowieka do drugiego. Ono dokonuje się przez to, że wszyscy są skierowani do tego samego celu i duchowo spoczywaja w tym samym ostatecznie punkcie: w Bogu, w tej samej wierze, ofierze i sakramentach" ${ }^{, 53}$. W liturgii są zachowywane granice między jednostkami, a „poczucie wspólnoty jest regulowane przez zawsze czujne poczucie dystansu, przez wzajemną cześć i szacunek. Pomimo istnienia wspólnoty, nigdy jeden człowiek nie może wciskać się we wnętrze drugiego człowieka, wywierać wpływu na jego modlitwę i działanie, narzucać mu swojego stylu życia, swoich uczuć i odczuć. Poczucie wspólnoty polega na usposobieniu, myślach i słowach, na skierowaniu oczu i serc na ten sam cel; polega na tym, że wszyscy w to samo wierza składają tę samą ofiarę i spożywają ten sam Boży chleb; polega na tym, że jeden Bóg i Pan wiąże wszystkich w tajemniczą jedność ${ }^{55}$.

\section{Styl liturgiczny}

Guardini przez pojęcie „styl” rozumie specyficzny rys, który nosi na sobie każda autentyczna, wartościowa forma jako taka: dzieło sztuki, osobowość, życie wspólne czy coś innego; jest to znak faktu, że „określona treść życia znalazła swój pełny i wyczerpujący wyraz" ${ }^{\text {"55 }}$. Jeśli jakaś osobowość, dzieło sztuki, forma życia społecznego, w sposobie swego bycia i działania przekonywująco wyraża czym ona jest sama w sobie, ale w tej swojej odrębności pozostając w łączności z życiem ogólnym, wtedy i o tyle ma ona styl. W tym sensie i liturgia ma swój styl; jest to: ,jasna mowa, płynny ruch, ścisłe przekształcenie przestrzeni, sprzętów, kolorów i tonów; wszystko - myśl, słowo, gest i obraz - wytworzone z prostych elementów życia duchowego; bogate, różnorodne, a jednak przejrzyste; a ostrość tego stylu wzmocniona jeszcze przez to, że liturgia posługuje się językiem wziętym z życia codziennego, a jednak klasycznym" ${ }^{\text {"56 }}$. Siła liturgicznej formy jest dla wiernego szkołą religijnego kształcenia ducha, a dla stojącego poza Kościołem objawia się jako obraz kultury najszlachetniejszego typu. Guardini uważa, że często te właściwości liturgii są dla dzisiejszego człowieka, nastawionego bardzo subiektywnie, pewną trudnościa; nie odpowiadają jego usposobieniom i upodobaniom. Do współczesnego chrześcijanina bardziej przemawia np. konkretna postać Jezusa z Ewangelii, a mniej obraz Jezusa z liturgii: pełen majestatu Pośrednik między Bogiem a człowiekiem, wieczny Arcykapłan, Boski Nauczyciel, Sędzia żywych i umarłych, Utajony w Sakramencie, Syn Boży, Słowo, które

\footnotetext{
${ }^{52}$ Tamże.

${ }^{53}$ Tamźe, s. 77.

${ }^{54}$ Tamże, s. 78.

${ }^{55}$ Tamże, s. 79.

${ }^{56}$ Tamże, s. 84.
} 
stało się Ciałem - takim jest On we Mszy św., takim w modlitwach liturgicznych ${ }^{57}$. W tej sytuacji styl liturgii: rzeczowy, jasny i wszystkim dostępny a przy tym prawdziwie katolicki tzn. powszechny, może być przyjęty przez każdego i umożliwić wyrwanie się z zamkniętego kręgu własnych spraw i wzniesienie się na wyżyny wspólnoty i nabycie w ten sposób, w liturgii, „,wielkiego stylu" życia duchowego ${ }^{58}$.

\section{Symbolika liturgiczna}

W liturgii wierny staje wobec bardzo bogatego w treść świata znaków i obrazów: gestów, ruchów, czynności, szat, przedmiotów materialnych kultu, znaczących miejsc i czasów. I powstaje pytanie, jakie znaczenie ma to wszystko w obcowaniu człowieka z Bogiem, skoro Bóg jest poza wszelką przestrzenią i czasem? Guardini, aby dać przekonywującą odpowiedź, rozważa wzajemny stosunek cielesności-materialności i duchowości, jaki istnieje w człowieku. Istnieją dlatego dwie możliwe postawy, odgraniczająca ducha od ciała w sposób zdecydowany i przyznająca każdemu z tych pierwiastków prawie pełną autonomię oraz postawa przyjmująca pełne, doskonałe zespolenie się obu tych elementów. Obie te postawy moga napotkać w liturgii specyficzne trudności, chociaż ta druga wydaje się być bliższa liturgii; obie także postawy duchowe mają udział w tworzeniu nowych symboli, za którymi ukazuje się pełna treści Boża Rzeczywistość ${ }^{59}$.

\section{Sens liturgii (Liturgia jako święta gra)}

Każdy kto patrzy na liturgię tylko pod kątem celowości może napotkać na swoiste trudności w jej zrozumieniu. Taką trudność odczuwają „poważnie usposobione natury, które są całkowicie nastawione na poznanie prawdy, które we wszystkim widzą zadanie moralne, wszędzie szukają celowości" ${ }^{60}$. Liturgia wydaje się im czymś sztucznym, a może teatralnym i przesadzonym w całej tej „obudowie" liturgicznych czynności i modlitw, skoro cel mógłby być osiągniętymi dużo prostszymi środkami. Na pytanie „po co to wszystko", które zdają się stawiać niektórzy ludzie, a który to zarzut Guardini bierze na serio i daje odpowiedź wskazując najpierw na problem celu i celowości w przyrodzie i w życiu człowieka. Cel nadaje życiu ludzkiemu powagę i kiernnek. Pojęcie celu jednak nie wyczerpuje całego bogactwa natury, dla zrozumienia której trzeba jeszcze wprowadzić pojęcie sensu. Sensem zaś każdej rzeczy jest to, że ona jest i że jest odbiciem nieskończonego Boga, a sensem istoty żywej jest to, ,żeby żyła, ukazywała swoje życie wewnętrzne i rozkwitała, jako naturalne objawienie żywego Boga" ${ }^{\text {"61 }}$. Cel i sens to są dwa bieguny bytu, które sq̨ również obecne w Kościele. Celem Kościoła jest zbawienie człowieka przez wypełnianie potrójnej władzy, a sensem czyli treścią życia Kościoła jest właśnie

\footnotetext{
${ }^{57}$ Tamże, s. 86.

${ }^{38}$ Tamże, s. 89.

59 Tamże, s. 97 n.

${ }^{60}$ Tamże, s. 99.

${ }^{61}$ Tamże, s. 102.
} 
liturgia, której nie można rozpatrywać tylko z punktu widzenia celu. Liturgia jest celem sama w sobie, a przez to jest pełna głębokiego sensu; , „liturgia (...) dlatego nie może mieć żadnego „celu”, ponieważ istnieje ona nie ze względu na człowieka, ale ze względu na Boga. W liturgii człowiek patrzy nie na samego siebie, ale na Boga"62. Sens liturgii, według Guardiniego, jest taki, „aby dusza była przed Bogiem, by się przed Nim wylewała, by żyła Jego życiem w świętym świecie Bożych Rzeczywistości, Prawd, Tajemnic i Znaków, a przez to posiadała swoje własne, prawdziwe, rzeczywiste życie" ${ }^{363}$. Liturgia, mówi R.Guardini, daje człowiekowi możliwość i okazję, by kierowany przez łaskę zrealizował najbardziej osobisty sens swego istnienia, by stał się w pełni takim, jakim powinien i może być, zgodnie z Bożym przeznaczeniem: „dzieckiem Bożym”. „W liturgii powinien on przed Bogiem „cieszyć się swoją młodością". To jest z pewnością coś całkowicie nadnaturalnego, ale właśnie dlatego odpowiadającego zarazem najbardziej wewnętrznej naturze"64.

Liturgię, która tak starannie i rygorystycznie określa w tysiącach przepisów, jakie słowa, gesty, kolory, szaty, sprzęty powinny być użyte, zrozumie ten, kto jest zdolny do poważnego traktowania zabawy i sztuki. Liturgia bowiem $\mathrm{z}$ całą powagą dziecka i z całą sumiennością wielkiego artysty trudziła się, aby w tysiącach form dać wyraz życiu duszy, świętemu, zrodzonemu z Boga - nie w żadnym innym celu, jak tylko w tym, by dusza w niej mogła być i żyć. „Poważnymi ustawami uregulowała ona świętą grę, jaką dusza prowadzi z Bogiem. Jeślibyśmy chcieli dotknać ostatecznej podstawy tej tajemnicy, to Duch Święty, Duch ognia i świętej dyscypliny, «który ma moc nad wszelkim słowem», jest Tym, który uporządkował tę grę, jaką Przedwieczna Mądrość prowadzi w Kościele, swoim Królestwie na ziemi przed obliczem Ojca Niebieskiego. «A jej rozkoszą", tak samo «jest przebywać wśród synów człowieczych»"65. „Sprawować liturgię, tzn., będąc niesionym przez łaskę i prowadzonym przez Kościół, stać się żywym dziełem sztuki przed Bogiem, w tym tylko celu, aby właśnie być i żyć w obecności Bożej; to znaczy wypełnić słowo Pana i «stać się jak dzieci»"

\section{Powaga liturgii}

Istnieje niebezpieczeństwo patrzenia na liturgię tylko pod kątem jej piękna i artyzmu, a niedostrzegania Rzeczywistości, jaka się w niej uobecnia; to niebezpieczeństwo jest tu dlatego większe, gdyż ,chodzi o ową potężną jedność rzeczywistości życia i formy artystycznej, jaka zbudował Twórca-Artysta, Duch Święty, gdy chodzi o Opus Dei liturgii"' ${ }^{67}$. Guardini przeprowadza bardzo dogłębną analizę pojęcia „piękno", przypominając starożytną zasadę filozoficzną: Pulchritudo est splendor veritatis, est species boni-Pięk-

\footnotetext{
${ }^{62}$ Tamże, s. 106.

63 Tamże.

${ }^{64}$ Tamże, s. 109.

65 Tamże, s. 111.

66 Tamże, s. 112.

${ }^{67}$ Tamże, s. 114.
} 
no jest odblaskiem Prawdy, rodzajem Dobra. Piękno jest wartością samą w sobie, ale znajduje sie w ścisłym stosunku przyporządkowania do Prawdy i Dobra. „Oznacza to, że aby Piękno mogło się pojawić, musi być coś, co może się na zewnątrz objawić, jakaś istotna prawda, która dąży do wyrażenia się, jakieś przeżycie, które chce się uzewnętrznić" ${ }^{68}$. Nie można odwracać porządku i stawiać Piękna przed Prawdą i Dobrem, gdyż ,jest to niebezpieczeństwo światopoglądu estetycznego, który ostatecznie kończy się na pozbawionym energii pięknie ducha"69. Kto chce żyć w Pięknie, musi najpierw starać się o Prawdę i Dobro, gdyż szukając Piękna dla niego samego, człowiek zniszczy swoje życie i dzieło, grzesząc przeciw zasadniczemu porządkowi wartości; ,jeśli jednak przeciwnie, człowiek nie pragnie niczego innego, jak tylko żyć w prawdzie, być prawym i mówić prawdę i trzyma swoją duszę otwarta, takiego człowieka Piękno spotka bez szukania, nieoczekiwanie jako wspaniała realizacja życia czystego, bogatego, przekształconego w formę ${ }^{970}$.

Powyższe prawdy mają pełne zastosowanie w liturgii. Piękno, jakie występuje w liturgii, wyrosło na podłożu wzniosłych i wielkich prawd wiary. W liturgii chodzi przede wszystkim o zbawienie człowieka i odkupienie zgubionej przez grzech ludzkości. To jest ta powaga liturgii, z której dopiero wypływa jej piękno. „Idzie tu o prawdę, o los duszy, o rzeczywiste, ostatecznie jedyne rzeczywiste życie. To wszystko winno być objawiane, mówione, szukane, osiagane, znajdywane, dawane wszystkimi środkami i sposobami ekspresji. I oto pojawiło się Piękno. Nic dziwnego, przecież Ten, który tutaj działał, to Duch Prawdy, który stworzył wszystkie rzeczy. To, co było wewnątrz, wypowiedziało się w szczerej prawdziwości; cała pełnia życia znalazła tu swój wyraz, przepastne głębie wyłoniły się w jasne formy... Ale dla nas liturgia musi być najpierw tylko sprawą zbawienia"71. Zrozumienie tej prawdy i powagi liturgii pozwala na odkrycie także jej piękna. Wydaje się słusznym zastosowanie tu jako reguły słów Ewangelii, którymi Guardini kończy ten rozdział: „Starajcie się naprzód o królestwa Boga i o Jego sprawiedliwość, a to wszystko będzie wam dodane"(Mt 6, 33), wszystko, także i przeżycie piękna ${ }^{72}$.

\section{Prymat Logosu nad Etosem}

Kościół nauczał od początku o pierwszeństwie metafizyki przed etyka, Logosu przed Etosem; a to nauczanie Kościoła ma zastosowanie również w liturgii, która zasadniczo nie daje konkretnych wskazań moralnych, jak należy postępować w poszczególnych przypadkach. „Liturgia natomiast ma przede wszystkim za cel stworzenie fundamentalnego usposobienia chrześcijańskiego. Pragnie ona doprowadzić człowieka do tego, aby on się ustawił we właściwej, istotnej relacji do Boga, aby poprzez modlitwę, cześć Bożą wiarę i miłość, usposobienie pokutne i ofiarne stał się wewnętrznie „sprawiedliwy”.

\footnotetext{
68 Tamże, s. 117 n.

${ }^{69}$ Tamże, s. 119.

${ }^{70}$ Tamże, s. 123

71 Tamże, s. 125.

72 Tamże, s. 126.
} 
Jeżeli następnie znajdzie się on w sytuacji zmuszającej go do działania, to z pewnością będzie czynił to, co prawe, kierowany tym wewnętrznym usposobieniem,"73.

Guardini, chcąc lepiej naświetlić stanowisko liturgii względem porządku moralnego, rozpatruje stosunek Logosu i Etosu w ujęciu historycznym, podkreślając, że w Średniowieczu prymat Logosu nad Etosem nie ulegał wątpliwości, a dopiero w nowszych czasach nastapiło tu odwrócenie porządku. Kościół jednak zawsze nauczał, że jest niezgodne z duchem katolickim dawanie pierwszeństwa Etosowi przed Logosem. Nieszczęściem naszych czasów jest odwrócenie tego świętego porządku natury (Goethe włożył w usta Fausta te słowa!) - zamiana zdania: „Na początku było Słowo” na: „Na początku był Czyn”. „W miarę jak punkt ciężkości życia przechodził z Poznania na Wolę, z Logosu na Etos, życie stawało się coraz bardziej pozbawione oparcia. Zażądano od człowieka, aby polegał na sobie samym. To może jednak (...) jedynie wola Boża. Zażądano od człowieka postawy suponującej, że jest on Bogiem. A ponieważ on Bogiem nie jest, do jego istoty wkrada się duchowa walka, gest bezsilnej gwałtowności, który u jednych przybiera wyraz tragiczny, a u innych po prostu śmieszny. To nastawienie jest winne, że dzisiejszy człowiek jest tak bardzo podobny do ślepca, który stapa w ciemnościach, bo podstawowa siła, na której oparł swoje życie, wola, jest ślepa. (...) Katolicyzm z całej siły przeciwstawia się temu nastawieniu duchowemu. Kościół łatwiej wszystko wybaczy, aniżeli atak na Prawdę" ${ }^{\text {?7 }}$.

Według Guardiniego w liturgii Logos ma przysługujące mu pierwszeństwo przed Wolą, ,stąd jej wspaniały spokój, jej głęboka cisza. Dlatego wydaje się ona rozkwitać w kontemplacji, adoracji i uwielbieniu Boskiej Prawdy. Stąd wydaje się ona tak niefrasobliwa wobec małych trosk dnia codziennego. Dlatego tak mało troszczy się ona bezpośrednio o wychowanie i nauczanie cnoty. Liturgia ma w sobie coś, co przypomina gwiazdy, ich wiecznie jednakowy bieg, ich niezmienny porządek, ich głębokie milczenie, nieskończoną przestrzeń, $\mathrm{w}$ której się znajdują. Liturgia jednak tylko $\mathrm{z}$ pozoru wydaje się mało troszczyć o działanie i dążenie, o moralny stan człowieka. Bo w rzeczywistości wie ona bardzo dobrze: kto nią żyje, jest prawy, zdrowy i zadowolony do głębi swej istoty"75.

\section{Znaki święte}

R. Guardini wydał tę książkę w 1923 r. (Von heiligen Zeichen), pisząc we wstępie, że powstawała ona na przestrzeni „mniej więcej lat dziesięciu” i wyjaśniając, iż została napisana, gdyż w liturgii chodzi przede wszystkim o rzeczywistość, nie o ideę. I to nie o rzeczywistość miniona, ale o tę teraźniej-

\footnotetext{
${ }^{73}$ Tamże, s. 128.

${ }^{74}$ Tamże, s. 134.

${ }^{75}$ Tamże, s. 138. Zob. omówienia tej ksiązki: J. R a d z i e jo w s k i, Romano Guardini i jego „, Duch Liturgil", HD 21(1952) 58-67; M. W o 1 i c k i , Stowo..., s. 35-47.
} 
sza, która dzieje się wciąż na nowo koło nas i przez nas; chodzi o ludzką rzeczywistość w dostrzegalnym kształcie i działaniu. Rzeczywistości tej nie przybliża ten, kto mówi: „Ona powstała wtedy a wtedy, rozwijała się w taki a taki sposób"; ani ten, kto przypisuje jej taki czy inny sens moralny; ale ten, kto pomaga odczytać $w$ widzialnym kształcie jego wewnętrzną istotę, w ciele jego duszę, a w ziemskim postępowaniu ukrytą cząstkę duchową. Liturgia jest sakramentalna, co oznacza, że jest światem spraw, które przybrały kształt, spraw, które są święte i zakryte; dlatego należy zapoznać się z owym żywym aktem, za pośrednictwem którego człowiek wierzący pojmuje, otrzymuje i sprawuje święte „znaki widzialne łaski niewidzialnej”. Chodzi zatem o liturgiczne wychowanie, o wskazówki, a przynajmniej o podniety do żywego oglądania i wykonywania „świętych znaków" "76. Z takim założeniem R. Guardini pisze w pierwszej części Znaków świętych o znaku krzyża, ręce, klęczeniu, postawie stojącej, pochodzie, biciu się w piersi, stopniach, furcie, świecy, wodzie święconej, ogniu, popiele i kadzidle. Znaki wyrażają zewnętrznie w sposób żywy i konkretny to, co człowiek przeżywa wcześniej wewnętrznie, w swoim sercu. Guardini uważał, że to, co napisał o znakach liturgicznych, przynajmniej wskaże „na coś, co należałoby dostrzegać i ku czemu winno się dążyć"; nie można jednakże zapominać, iż droga do życia liturgicznego wiedzie nie przez samo nauczanie, ale przede wszystkim przez czyn. „Patrzenie i działanie - to właśnie siły zasadnicze, w których pogrążać się musi reszta. Rzecz oczywista, że wszystko winno być oświecone jasną nauka, a w związku $\mathrm{z}$ tradycją katolicką opartą na wywodach historycznych. Ale głównie musi tu być czyn (...). Czyn musi być żywym sprawowaniem i żywym doznawaniem, patrzeniem, pojmowaniem" "77. Wyjaśniając np. czym jest znak krzyża, Guardini pisał m.in.: „Oto czynisz znak krzyża, czynisz go w sposób właściwy. Nie jest to jakiś tam gest niezdarny i pospieszny, nie wiadomo, co oznaczający. Nie! Czynisz należyty znak krzyża, powolny, duży, od czoła do piersi, od jednego ramienia do drugiego. Czy czujesz, jak on obejmuje ciebie całkowicie? (...) Czemuż to? Bo jest on znakiem wszystkiego i jest znakiem zbawienia. $\mathrm{Na}$ krzyżu Pan nasz odkupił wszystkich ludzi. Przez krzyż uświęca człowieka aż do najmniejszej tkanki jego istoty" ${ }^{98}$. Inny z wielu znaków, na który zwraca uwagę Guardini to postawa stojąca oznaczająca, „że bierzemy w karby samych siebie”, przybieramy postawę „znamionującą karność i opanowanie”. „Jest to znak, że uważamy. W staniu wyraża się naprężenie i czujność. Jest ono też oznaką gotowości: bo kto stoi, może natychmiast wyruszyć w drogę, może bez zwłoki wykonać polecenie, przystapić zaraz do roboty, jaka mu wyznaczono. (...) Pewno znasz spotykany często w katakumbach wizerunek „oranta”, stojącego $\mathrm{w}$ dostojnie spływającej szacie $\mathrm{z}$ rozpostartymi ramionami. Postać ta stoi swobodnie, pełna jasnego ładu, spokojnie słuchając słowa gotowa do radosnego czynu"79.

\footnotetext{
${ }^{76}$ Zob. R. G u a r d in i, Znaki święte, Wroclaw 1982, s. 17 n.

${ }^{77}$ Tamże, s. 19-21.

${ }^{78}$ Tamże, s. 25.

${ }^{79}$ Tamże, s. 32.
} 
R. Guardini opisuje w drugiej części swej Von heiligen Zeichen dalsze znaki, które są rzeczami lub wydarzeniami, stworzonymi przez Boga bądź wytworzonymi przez człowieka, takie jak: żar i światło, chleb i wino, ołtarz, płótno, kielich, patena, błogosławieństwo, święta przestrzeń, dzwony, czas uświęcony, Imię Boże.

Z punktu widzenia odbiorcy najważniejsze dla Guardiniego jest to, aby każdy dostrzegł obecność Boga, choćby nawet znak nie był w stanie za wiele powiedzieć mu o owej obecności. „Obecność Boga w świecie oraz w nas samych jest oczywiście dla nas tajemnica. Jest ona na pewno wieloraka, tak jak wielorakie jest działanie Boże, gdyż obecność ta nie dokonuje się inaczej, jak tylko w działaniu i przez działanie. Bóg wzywa nas do współdziałania z Nim i każdy znak jest $w$ jakimś sensie takim wezwaniem Bożym do nas skierowanym" ${ }^{\prime 80}$. Boże działanie zarówno w świecie przyrody (znaki naturalne), jak i w świecie tworzonym przez człowieka (znaki „ludzkie"), ma zawsze swoje odniesienie do człowieka, pod warunkiem, że potrafi on "odczytać" w tych znakach obecność Boga i zrozumieć Jego wezwanie. R. Guardini pomaga w tym niewielkim omówieniu kilkunastu znaków, dostrzegać obecność Boga i przyjąć, skierowane do każdego, Jego wezwanie. Dlatego, dla Guardiniego, znakiem jest ,zarówno sam człowiek, jego ręka, jego postawa, jego zachowanie się, jak i rzeczy przez Boga stworzone (ogien, światło, przestrzeń, czas), lub wytworzone przez człowieka, aby mu służyły (stopnie, furta, płótna), lub ażeby były znakiem (woda święcona, kadzidło, patena, ołtarz); znakiem są wreszcie słowa święte (błogosławieństwo)"ק1. Aktualność rozważań Guardiniego polega na tym, że pomagają one, jak przed laty, dostrzegać, rozpoznawać i rozumieć znaki święte, którymi Bóg dziś przemawia do nas, i z którymi spotykamy się przede wszystkim w liturgii.

\section{Przedszkole modlitwy}

R. Guardini zmierzał swoją działalnością duszpasterską, a zwłaszcza publicystyczną, do tego, aby doprowadzić współczesnego człowieka „do urzeczywistnienia chrześcijaństwa $\mathrm{w}$ osobistym obcowaniu z Bogiem" "\$2 . Ważną część tego posłannictwa wypełniał Autor w niewielkiej książce, skromnie nazwanej Przedszkolem modlitwy (Vorschule des Betens), napisanej w czasie wojny, w 1943r., która, tak jak inne, powstała ,z wewnętrznej potrzeby wyrażenia słowem tego, co składa się na moje życie" ${ }^{, 83}$. R. Guardini chciał uczyć jedynie „prostych rzeczy" i prowadzić czytelników do praktycznego działania; dlatego książka ta łączy w sobie dwa najważniejsze nurty w jego twórczości: rozważania poświęcone chrześcijańskiej rzeczywistości Boga i wywody poświęcone człowiekowi wraz ze wszystkimi jego troskami, kłopotami i zwąt-

\footnotetext{
${ }^{80} \mathrm{~J} . \mathrm{M} \mathrm{aj} \mathrm{k} \mathrm{a,} \mathrm{Wprowadzenie,} \mathrm{[w:]} \mathrm{R.} \mathrm{G} \mathrm{u} \mathrm{ard} \mathrm{in} \mathrm{i,} \mathrm{Znaki..,} \mathrm{s.} 13$.

${ }^{81}$ Tamże, s. $13 \mathrm{n}$.

${ }^{82}$ W. B e ck e r, Stowo od wydawcy niemieckiego, [w:] R. G u ardin i, O Bogu ży-

${ }^{83}$ Tamże, s. $76 \mathrm{n}$.
} wym, Warszawa 1987, s. 75. 
pieniami. R. Guardini thumaczył, że jego dzieła nie powstawały według ścisłego jakiegoś planu, ale $\mathrm{z}$ potrzeby dania odpowiedzi na to, co w danym czasie przynosiła konkretna sytuacja religijna, społeczna czy polityczna, spotkanie z ludźmi, bądź np. widok dzieła sztuki ${ }^{84}$.

Przedszkole modlitwy R. Guardini poświęcił podstawowym i praktycznym problemom modlitwy, uwzględniając w kontekście teologicznym także aspekt psychologiczny i podkreślając potrzebę ćwiczenia, tak istotnie związaną ze spontanicznym pragnieniem modlitwy. Guardini uważał, że modlitwa jest wewnętrzną koniecznością, łaską i spełnieniem, ale także obowiązkiem, wysiłkiem oraz trudem przełamywania wewnętrznych oporów. Modlitwa ma swoje źródło i szkołę, a właściwie szkoły różnych stopni. Przede wszystkim jest szkoła nakreślona w Nowym Testamencie przez samego Jezusa Chrystusa, a następną szkołą modlitwy jest ta, którą Kościół zawarł w swojej liturgii. „To jedyna $\mathrm{w}$ swoim rodzaju modlitwa łącząca $w$ sobie słowo i działanie, mowę i śpiew. Rozwija się wraz z biegiem lat, przenika całe życie; zawiera się w niej tysiącletnia mądrość modlitwy" ${ }^{85}$. Jest wreszcie szkołą wielkich świętych żyjących w obcowaniu z Bogiem w wyjątkowy sposób, którzy swoje doświadczenia zawarli w bezcennych pismach. Autor jest zdania, że „każde czasy potrzebują świadomej i mocnej modlitwy - nasze (1943r.!) szczególnie"! Guardini mówi o konieczności skupienia i przygotowania się do modlitwy, oraz o różnych jej formach, takich jak: modlitwa ustna, mistyczna (kontemplacyjna), modlitwa do Świętych i do Matki Pana, modlitwa w czasie niemocy. Wyjaśniając istotę modlitwy osobistej i liturgicznej, Guardini stwierdza, że „modlitwa osobista dokonuje się $w$ poruszeniu serca i w słowach, a tylko nieznacznie przechodzi $w$ gest $\mathrm{i}$ działanie; natomiast liturgia jest przede wszystkim działaniem i modlitwa stanowi jedynie część jej spełniania. (...) W modlitwie osobistej człowiek jest sam z Bogiem; liturgię sprawuje całe chrześcijańskie zgromadzenie. Tutaj nie nazywa się to ,ja”, lecz „my”. I owo „my” nie oznacza, że zeszło się wiele pojedynczych osób. To nie suma, lecz całość: Kościół" ${ }^{\prime 6}$. Przedszkole modlitwy Guardiniego niosło przesłanie, iż w liturgii człowiek wychodzi ze swej odrębności i staje się członkiem całości, żywego organizmu, w którym wyrażają się wielkie, obiektywne słowa i działania Kościoła. Udział w liturgii sprawia, że człowiek otwiera się na poryw płynący z głębi serca Kościoła, „które bije przez tysiąclecia”87.

Sobór Watykański II stwierdził w Konstytucji o liturgii świętej, że postawił sobie za cel: większy rozwój „życia chrześcijańskiego wśród wiernych”, popieranie tego, „co może ułatwić zjednoczenie wszystkich wierzących

\footnotetext{
${ }^{84}$ Tamże, s. 77.

${ }^{85}$ R. G u a rd in i, Przedszkole modlitwy, [w:] R. G u ar d in i, O Bogu..., s. 79.

${ }^{86}$ Tarnże, s. 201.

${ }^{87}$ Tamże, s. 202.
} 
w Chrystusa” oraz umocnienie tego, „co prowadzi do powołania wszystkich ludzi na łono Kościoła" (KL 1). Drogą do osiągnięcia tego celu jest odnowienie i rozwój liturgii, gdyż właśnie liturgia, w której „dokonuje się dzieło naszego Odkupienia", w najwyższym stopniu przyczynia się do tego, aby wierni życiem swoim wyrażali oraz ujawniali innym misterium Chrystusa i rzeczywistą naturę prawdziwego Kościoła" (KL 2).

Wydaje się, że wskazane przez Sobór odnowienie życia wiary w Kościele, będzie się stawało dostrzegalną rzeczywistością jeśli prowadząca do tego celu odnowa liturgiczna zostanie podjęta zwłaszcza przez duszpasterzy, „przenikniętych duchem i mocą liturgii” (por. KL 14). Trzeba, aby stali się oni jej „nauczycielami” i podjęli to posłannictwo $z$ entuzjazmem wielkich inspiratorów i prekursorów tej odnowy, z których dwóch zostało ukazanych jako wymowny wzór, mimo upływu kilkudziesięciu lat, nie pomniejszający ich aktualności i nie osłabiający ich oddziaływania. 